\title{
An Offering of Hope During COVID-19: A Personal Reflection
}

\section{Mary Simmerling ${ }^{1}$ (ID}

Published online: 30 July 2020

(c) Springer Science+Business Media, LLC, part of Springer Nature 2020

\begin{abstract}
This essay offers a philosophical and spiritual exploration of some of the language that has become part of daily life amidst the COVID-19 crisis.
\end{abstract}

Keywords COVID-19 · Pandemic · Language · Ethics · Philosophy · Poetry · Healing · Grace $\cdot$ Hope

\section{Introduction}

As I have struggled personally to cope with the current global health crisis, I have found myself returning to activities and rituals that have been a source of comfort and solace for me in the past. As a philosopher, I have sought truth and meaning in language and words. And as a poet, I have not so much turned to language and written words but been awoken by these as a means of expressing my own truths, fears, sorrows, hopes, and joys. These past weeks and months I have found myself living with and among words both unfamiliar and heavy. Thinking about what these mean. How these changed so many things.

I realized that I was engaged in an activity that was part meditation, part excavation, and part prayerful poem. I also realized that it wasn't just mine. So I wish to share this as an offering of sorts that it may provide some hope and perhaps even a balm in this terrifying and lonely time during which so many of us are isolated and afraid. Perhaps others will come together to explore these words that—once distant and unknown - have become so pervasive in our lives. I have used my native English for my own exploration, but am hopeful others may choose to adapt and explore this in the many other languages in which we have heard and seen fears, hopes, and prayers expressed over the past months. Those that have been uttered and those that have been silently shared.

Mary Simmerling

mary.simmerling@gmail.com

1 Weill Cornell Medical College, Cornell University, New York, USA 


\section{Pandemic}

The one word that has loomed large at the start of and throughout the current crisis is "pandemic." The World Health Organization was initially reluctant to even officially declare a pandemic (Editorial 2020). As discussion and debate sprang up around this single word, its heaviness began to weigh upon me. At the same time, the return of some of the simplicity of life pushed indoors - puzzles and crayons and stories - reminded me of word games I would sometimes play as a child (like Jumble and Scrabble) when I was bored and it was raining or too cold to want to venture out to play with friends. As I thought about these simple childhood games and this new word (pandemic) that seemed to suddenly permeate every aspect of life, I began to use my childhood tools to explore its power (Table 1).

In my excavation, I found so many sorrowful and frightening words. PANDEMIC. And in my despair I remembered that this was not the only new word that had insinuated itself into our daily lives. Two others also seemed to be everywhere all at once. COVID-19 and GLOBAL. So I wrote these down too. And almost immediately I felt a visceral need for the $\mathrm{V}$ and the L. With these, I had found something to hold. I took my pen and I very gently wrote LOVE. Looking at it there on the same paper, it stood out as a humble and solitary rebuke of PANDEMIC.

Table 1 Creative word game PANDEMIC

\begin{tabular}{ll}
\hline PANDEMIC & \\
Panic & Panic \\
Pain & And \\
Name & Pain \\
Pandemic & Came \\
Mad & Pain \\
Anemic & I \\
And & Am \\
Dim & In \\
Me & Panic \\
Mine & And \\
Men & Pain \\
Manic & Pandemic \\
Die & \\
End & Medic \\
Damn & Aid \\
Pandemic & Mind \\
\hline
\end{tabular}




\section{The Letter "H"}

Then I wanted an H. Could I find an H? I felt so greedy. I needed an H. I wanted HOPE. And I wanted HEAL. And I wanted even more than that. I could feel my heart begin to race. I stopped to think about where to find an $\mathrm{H}$. And my mind drifted to thoughts of my friends and colleagues on the front lines in New York and Chicago, like firefighters running into burning buildings selflessly trying to save strangers because that is what they do. But these raging fires are racing through hospital hallways, touching everyone in their paths. The heroes who are cleaning floors and emptying garbage. Those who are taking temperatures, answering phones, delivering supplies to loading docks. Those who are caring for the sick, who are arriving at their doors afraid and alone. Our healthcare workers who have become not only caregivers but spiritual warriors making sure that those who arrive alone do not die alone (Gonzalez and Nasseri 2020). I thought of my sisters and brothers and nieces and nephews who each in their own way were going into battle every day-tending to the sick in an urgent care, refocusing research on understanding this new virus and working toward a cure, pivoting from creating art to bagging groceries to keep people fed. And of the many, many people volunteering to make sure that those who are sheltering in place at risk of harm will be reassured by a voice of calm and care when they call for help (RAINN 2020).

So much heroism. So much kindness. So much sacrifice, humility, and humanity.

\section{JUSTICE}

As a graduate student, I spent years focused on understanding the meaning of another word: JUSTICE. Trying to understand and untangle justice, respect, autonomy, and fairness - all related to bioethical principles acknowledged to be vitally important for pastoral and spiritual care (Carey and Cohen 2015). In the end, I could not separate these as clearly as so many before me had tried to do. Because it turns out that justice is not a simple word. Necessarily contained within it are FAIRNESS and RESPECT. JUSTICE cannot be-it cannot mean what it is meant to be-without these essential components. And so too, I remembered that in LOVE there are also HOPE, HELP, and HEALING. In LOVE there are GENEROSITY, UNDERSTANDING, COMPASSION. That LOVE can lessen the burdens of PANDEMIC. That LOVE can make these bearable.

\section{LOCAL, GLOBAL, HOPE}

I saw that with COVID-19 and GLOBAL, I could also write LOCAL and GLOBAL. LOVE, LOCAL, GLOBAL. And I was returned once again to a place of hope. To a place where it is possible to live with fear, balanced as it can be by a belief in a goodness so pure and essential that I feel it every time I take my son's hand in my own. To a place of grace. And I know right now that it is that same belief in goodness that 
is spreading through the gloved hands of all those who are living with fear while they battle to end this pandemic. We need look no further than their acts-the simple, the heroic, and the simply heroic - to know that hope has not yet run its course.

LOCAL

\section{GLOBAL}

LOVE

DIVINE

CLERIC

MEDIC

MEND.

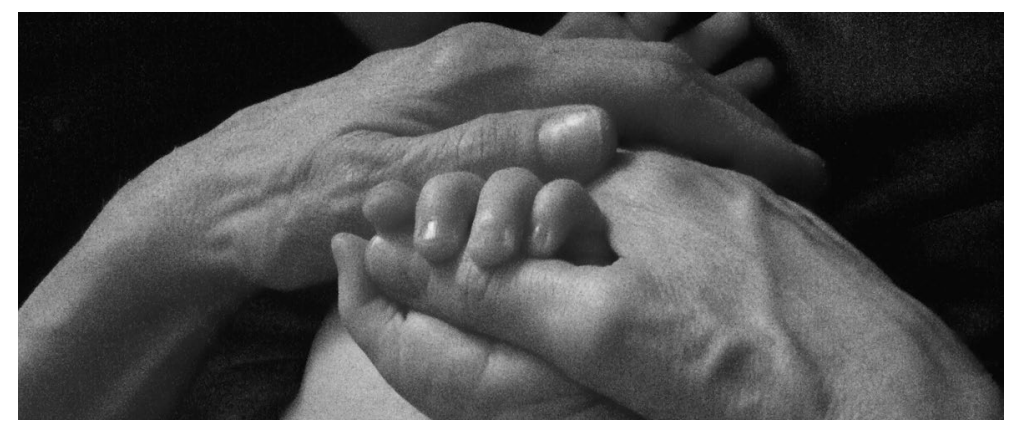

Funding This work was not funded.

\section{Compliance with Ethical Standards}

Conflict of interest The author has no conflicts of interest to report.

Ethical Standards This work is original work created solely by the author and complies with all applicable ethical standards.

Research Involving Human Participants and/or Animals Not applicable-this manuscript did not involve human participants or animals.

Informed Consent Not applicable. 


\section{References}

Carey, L. B., \& Cohen, J. (2015). Pastoral and spiritual care. Henk Ten Have (pp. 1-14)., Encyclopedia of Global Bioethics New York: Springer. https://doi.org/10.1007/978-3-319-05544-2_326-2.

Editorial. (2020). COVID-19, a pandemic or not? The Lancet Infectious Diseases, 20(4), 383. https:// doi.org/10.1016/S1473-3099(20)30180-8.

Gonzalez, D, \& Nasseri, S. (2020). 'Patients Have Panic in Their Eyes': Voices From a Covid-19 Unit. The New York Times. Retrieved May 22, 2020 from https://www.nytimes.com/2020/04/29/ nyregion/coronavirus-nyc-hospitals.html?searchResultPosition=66.

RAINN (Rape and Incest National Network). (2020). COVID-19 Update: RAINN is Here for Survivors. Retrieved May 22, 2020 from https://www.rainn.org/news/covid-19-update-rainnhere-survivors.

Publisher's Note Springer Nature remains neutral with regard to jurisdictional claims in published maps and institutional affiliations. 